\title{
THE KSOUR OF THE MDAGRA OASIS (ER-RACHIDIA, MOROCCO): AN INVENTORY
}

\author{
T. Gil-Piqueras ${ }^{1,2, *}$, P. Rodríguez-Navarro ${ }^{1,2}$ \\ ${ }^{1}$ Dept. Architectural Graphic Expression, Universitat Politècnica de València, Spain - (tgil@ega.upv,es, rodriguez@upv.es) \\ ${ }^{2}$ Research Centre PEGASO, Universitat Politècnica de València, Valencia, Spain
}

\section{Commission II - WG II/8}

KEY WORDS: Mdagra, Ksar, Fortified Architecture, Vernacular Architecture, Rammed Earth, Pre-Saharan Oasis, Morocco

\begin{abstract}
:
The Mdagra Oasis is located in the province of Er-Rachidia, in southern Morocco. The objective of this contribution is to present an unparalleled inventory of the ksour existing in that oasis, the result of several years of study and field exploration. During the Saadi period ( $16^{\text {th }}$ century), this area of the Ziz basin was a compulsory stop for traders on the route of caravans crossing the High Atlas. Later, during the Alauita period, the area was consolidated, and for more than 400 years many important cities were constructed using rammed earth, as Ksar es Souq or Sidi Bou Abdellah Ksar. This is how the oasis came to have an important community integrated by Berbers, Arabs and Jews. Today, most of the oasis' ksour are abandoned for different reasons and remain in a state of advanced ruin. Through fieldwork, we have been able to identify, record, analyze and classify 53 earthen human settlements, providing an unprecedented study of all of them. Subsequently, a first typological classification was proposed based on aspects such as the implementation in the territory, the external morphology, the urban organization, or the occupation area. The ultimate goal was to document this rammed earth, at-risk heritage since we have witnessed its rapid degradation, and even disappearance in some cases, throughout this investigation.
\end{abstract}

\section{INTRODUCTION}

The Mdagra oasis is located in the upper stretch of the Ziz River, southeast of the Moroccan High Atlas. Its $24 \mathrm{~km}$. in length belong to the Er-Rachidia province, located in the Meknès-Tafilalt region. Its natural boundaries are: the oasis of Khenkh to the North and the Rteb oasis to the South, both belonging to the $\mathrm{Ziz}$ valley. The river bed is straight and runs in a north-westerly to south-easterly direction with a slope of $110 \mathrm{~m}$., giving rise to a fertile area of about $29 \mathrm{~km} 2$ characterized by its large palm grove and numerous olive trees.

Due to its geographical location, the oasis has historically occupied a privileged position, as it was a mandatory place of passage for merchants and travellers following the trade route between Fez and Sijilmassa, crossing the country's inland mountain range between the 8 th and 17 th centuries ${ }^{1}$. Along this route, in addition to slaves, it circulated highly valued merchandise such as gold, ivory, ostrich feathers and kola, products of great demand at the times, which were then distributed throughout the Mediterranean.

Within the oasis we find from small villages to important rammed earth cities, all of them complying with the ksar typology (Rodríguez-Navarro, Gil-Piqueras, 2015, p. 87). The first references found on some of these ksour date back to the 16th century, although they may have existed before that time (Jacques-Meuniè, 1982, p. 128). This is the case of Sidi Bou Abdellah, considered by some authors (Terrase, 1938) as an important religious-military center (zaouia); or Ksar es Souq, integrated by a group of five ksour, which housed in its central part a market having a mellah ${ }^{2}$ (Foucauld, 1888).

\footnotetext{
* Corresponding author

1 During the 16th century, the traffic on this caravan route was reduced due to the large number of robberies, a significant part of the trade
} being diverted along the Drâa route. The geographical conditions of

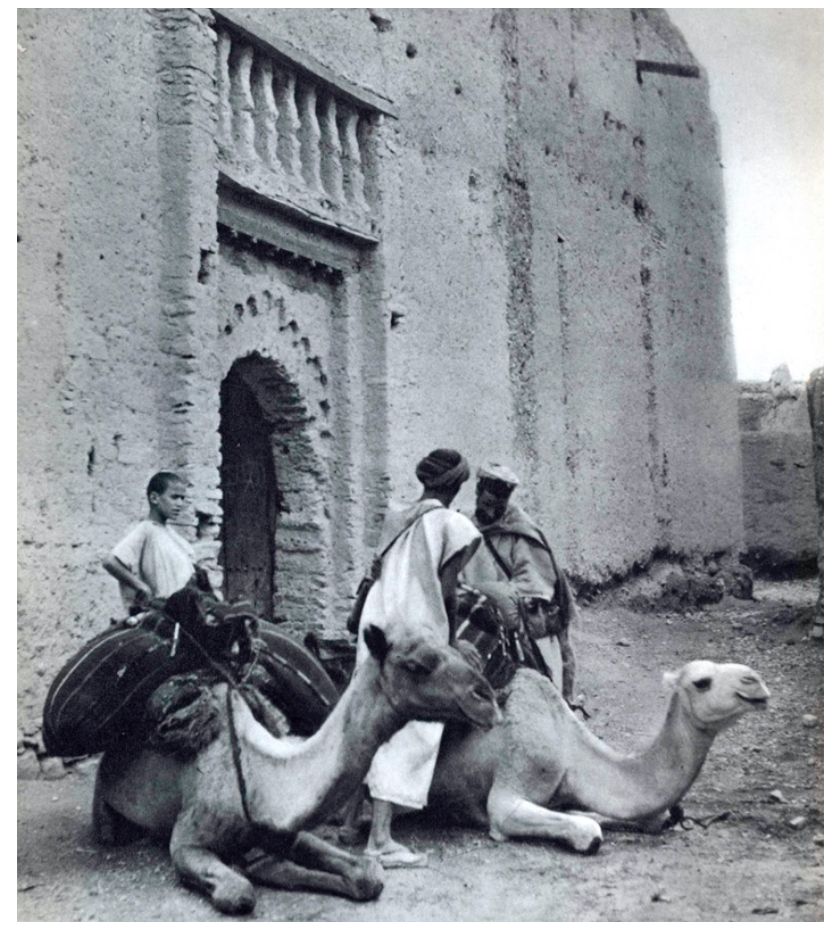

Figure 1. Tafilalt merchants. Source: Jacques-Meunié, 1951.

\subsection{Background and purpose of the investigation}

The study of earthen architecture in the Mdagra oasis arises almost parallel to that carried out between 2011 and 2015 in the Outat valley ${ }^{3}$.

the Tiallaline oasis and the Ziz Gorges facilitate these attacks. (Jacques-Meunié, 1982, p. 405-406).

2 Jewish quarter.

3 Research carried out in the frame of the Project "Estudio de la Arquitectura Habitacional de Tierra en el Alto Atlas Septentrional, 
The fact of finding architecture typical of the pre-Saharan oases in a mountain area such as that of the Outat River, led us to study its origin following the course of the river basins converging at the top of the mountain range. This is how we arrived in the Er-Rachidia province, and specifically to the Mdagra oasis. After a first inspection of the oasis, and given its magnitude, we decided to deepen in the study of its architecture, documenting all its ksour.

Our work was based on the records by Charles de Foucauld, back in 1882-1886, during his expedition through Morocco (Foucauld, 1888 , p. 351-352). In it, in addition to mentioning the ksour according to the river bank in which they were, he made reference to their demography, using as measuring unit the number of rifles, understanding that a rifle is equivalent to the size of a man in age of fighting. In his journey through the Mdagra oasis, Foucauld divides the oasis into two districts: the one located North to the current Er-Rachidia, known as the "Ksar es Souq" district and the one located to the South, known as the "Metrara" district. Between the two he accounted for 36 populated areas, which include a total of $42 \mathrm{ksour}$. In the following table, we enumerate Foucault's listing from North to South ${ }^{4}$ :

\begin{tabular}{|c|c|c|c|}
\hline \multicolumn{2}{|c|}{ West riverbank of the Ziz } & \multicolumn{2}{|c|}{ East riverbank of the $\mathrm{Ziz}$} \\
\hline Ksar name & No. Rifles & Ksar name & No. Rifles \\
\hline Tazouqa & 200 & Tiriouin & 150 \\
\hline Tagnit & 40 & $\begin{array}{l}\text { Beni Ouarain (3 } \\
\text { ksour) }\end{array}$ & 100 \\
\hline $\begin{array}{l}\text { Ksar es Souq: } \\
\text { Mouskellal, Qciba, Aït } \\
\text { Moha ou Ali, El Haratin, } \\
\text { Agaouz y Azrou }\end{array}$ & 300 & Er Rahba & 60 \\
\hline Tisgelat & 100 & $\begin{array}{l}\text { Qçar Djedid Ait } \\
\text { Hammou (3 ksour) }\end{array}$ & 60 \\
\hline Tarzout (2 ksour) & 100 & & \\
\hline Azemmour & 150 & & \\
\hline Targa (2 ksour) & 150 & & \\
\hline
\end{tabular}

Table 1. Ksour of the "Ksar es Souq" district (Foucauld, 1888).

\begin{tabular}{|c|c|c|c|}
\hline \multicolumn{2}{|c|}{ West riverside of the $\mathrm{Ziz}$} & \multicolumn{2}{|c|}{ East riverside of the $\mathrm{Ziz}$} \\
\hline Ksar name & No. Rifles & Ksar name & No. Rifles \\
\hline Tisgelat & 40 & Oulad el Haj & 300 \\
\hline Beni Mehelli & 100 & Qçar Dekhlani & 150 \\
\hline Asrir & 200 & El Rrouch & 40 \\
\hline Mediouna & 20 & Qçar Djedid & 100 \\
\hline El Hibous & 400 & $\begin{array}{l}\text { Zaouia Moulei Abd } \\
\text { Allah }\end{array}$ & 20 \\
\hline Qaçba Qedima & 400 & Qçar el Berrani & 100 \\
\hline & & Taourirt & 100 \\
\hline & & Sidi Bou Abd Allah & 300 \\
\hline & & Titaf & 200 \\
\hline & & Qaçba Djedida & 200 \\
\hline & & Beni Mousi & 300 \\
\hline & & Geri Ourgaz & 40 \\
\hline & & Gaouz & 100 \\
\hline & & Tazenagt & 400 \\
\hline
\end{tabular}

Table 2. Ksour of the "Metrara" district (Foucauld, 1888).

Midelt (Marruecos): Categorización, Sostenibilidad y Puesta en Valor del Patrimonio Arquitectónico para Contribuir a la Descentralización y el Desarrollo Sostenible", financed by the ADSIDEO-Cooperación 2011, call for Research Projects and Primeros Proyectos de Investigación of the UPV. PI: Pablo Rodríguez-Navarro.

\subsection{Methodology of the study}

In a first approach, we resorted to the Google Earth viewer to locate the ksour of the Mdagra oasis. Thus, we obtained the ortho images of its plans, on the same scale, which we enclosed with the information of the year of the photographic shooting and its coordinates, both geographical and UTM, to facilitate its subsequent search by means of a Global Position System (GPS) or from of a cartographic map.

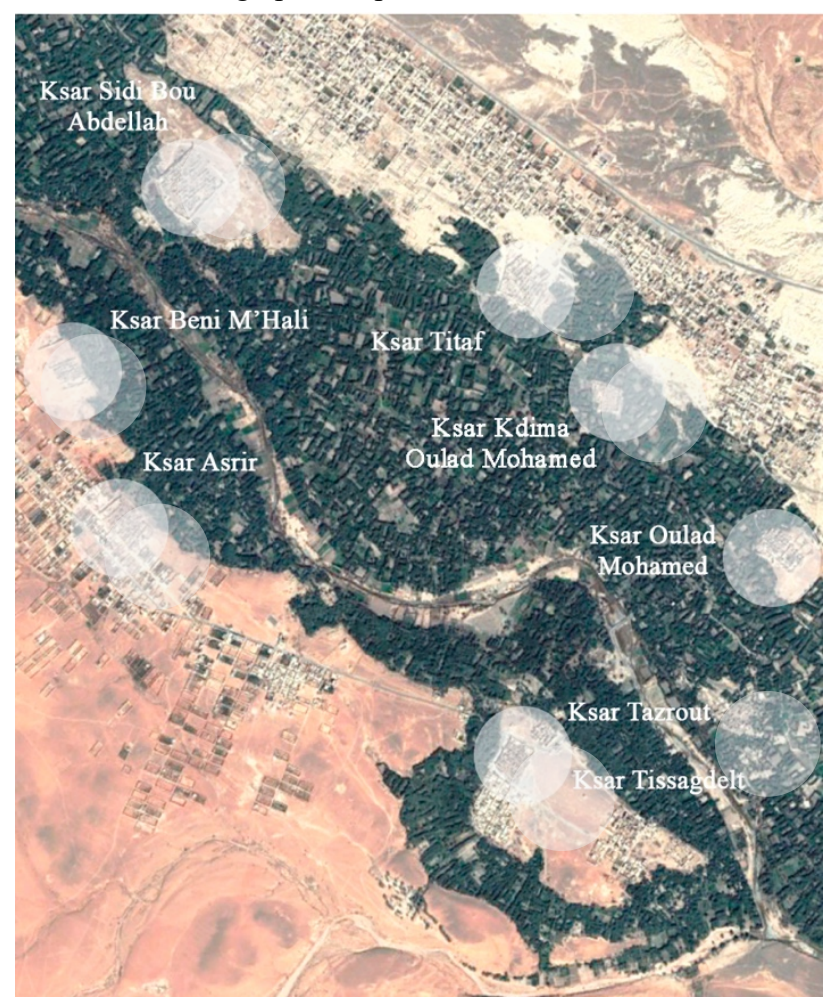

Figure 2. Location of ksour on orthoimage. Source: Google Earth.

Subsequently, several expeditions to the area were made in different years. To explore the oasis, we relied on cartographic maps published by the Division of the Catographie of the Directorate of Conservation Foncière et des Travaux Topographiques and on satellite photographs. For the field work, ad hoc record cards were used, in which we documented the different aspects related to their establishment in the territory, exterior morphology, interior organization, construction system and materials used, as well as available facilities for community use and the type of house.

Mosques, hammams, fortified entrances, houses and oil mills in which the olive was processed to obtain oil in ancient times, something very common in this oasis, were drawn through field sketches. The state of abandonment in which most of the ksour are found today facilitated this work, being able to access almost all of them.

The analysis of the data has allowed us to study and compare their morphologies and their urban organization, as well as the use of materials and systems, as appropriate

4 The listing of ksour has been transcribed as spelled by Foucauld in his book. Thus, some differences regarding the spelling of the names used in the rest of the article may be found. (FOUCAULD, 1888, p. 351-352. 


\section{RECORDING OF THE KSOUR IN THE MDAGRA OASIS}

After years of research, we have documented a total of $53 \mathrm{ksour}$ in the area delimited by the Mdagra, which attend to very diverse morphologies and sizes. The following includes the ksour inventoried at the Mdagra oasis:

\begin{tabular}{|c|c|}
\hline Ksar name & Geographical Coordinates \\
\hline 1 EP Tizuka & $31^{\circ} 58^{\prime} 44.81^{\prime \prime} \mathrm{N} ; 4^{\circ} 27^{\prime} 53.28^{\prime \prime} \mathrm{W}$ \\
\hline 2EP Tighiourine & $31^{\circ} 58^{\prime} 40.12^{\prime \prime} \mathrm{N} ; 4^{\circ} 27^{\prime} 21.36^{\prime \prime} \mathrm{W}$ \\
\hline 3EP Ibaghaden & $31^{\circ} 58^{\prime} 25.86^{\prime \prime} \mathrm{N} ; 4^{\circ} 27^{\prime} 28.52^{\prime \prime} \mathrm{W}$ \\
\hline 4EP Kasbah Ait Zammou & $31^{\circ} 58^{\prime} 19.51^{\prime \prime} \mathrm{N} ; 4^{\circ} 27^{\prime} 27.26^{\prime \prime} \mathrm{W}$ \\
\hline 5EP Ait Ouaraine Akedim & $31^{\circ} 58^{\prime} 16.80^{\prime \prime} \mathrm{N} ; 4^{\circ} 27^{\prime} 29.76^{\prime \prime} \mathrm{W}$ \\
\hline 6WP Tagounite & $31^{\circ} 58^{\prime} 15.55^{\prime \prime} \mathrm{N} ; 4^{\circ} 28^{\prime} 14.66^{\prime \prime} \mathrm{W}$ \\
\hline 7WP Mouchkelal & $31^{\circ} 58^{\prime} 09.09^{\prime} \mathrm{N} ; 4^{\circ} 28^{\prime} 05.55^{\prime \prime} \mathrm{W}$ \\
\hline 8WP N'Ait Moha Ou Ali & $31^{\circ} 58^{\prime} 07.47^{\prime \prime} \mathrm{N} ; 4^{\circ} 28^{\prime} 02.02^{\prime \prime} \mathrm{W}$ \\
\hline 9WP Taghzout & $31^{\circ} 58^{\prime} 01.61^{\prime \prime} \mathrm{N} ; 4^{\circ} 28^{\prime} 02.99^{\prime \prime} \mathrm{W}$ \\
\hline 10EP Rahba Kedima & $31^{\circ} 58^{\prime} 10.90^{\prime \prime} \mathrm{N} ; 4^{\circ} 27^{\prime} 28.35^{\prime \prime} \mathrm{W}$ \\
\hline 11EP Rahba Jdida & $31^{\circ} 58^{\prime} 04.63^{\prime \prime} \mathrm{N} ; 4^{\circ} 27^{\prime} 25.92^{\prime \prime} \mathrm{W}$ \\
\hline 12EP Ait Akka & $31^{\circ} 58^{\prime} 00.19^{\prime \prime} \mathrm{N} ; 4^{\circ} 27^{\prime} 20.40^{\prime \prime} \mathrm{W}$ \\
\hline 13EP Ait El Haj Housseine & $31^{\circ} 57^{\prime} 57.29^{\prime \prime} \mathrm{N} ; 4^{\circ} 27^{\prime} 13.71^{\prime \prime} \mathrm{W}$ \\
\hline 14EP Ait Arabt Oujdid & $31^{\circ} 58^{\prime} 01.43^{\prime \prime} \mathrm{N} ; 4^{\circ} 26^{\prime} 59.03^{\prime \prime} \mathrm{W}$ \\
\hline 15EP Ait Arabt Akedim & $31^{\circ} 57^{\prime} 50.33^{\prime \prime} \mathrm{N} ; 4^{\circ} 26^{\prime} 52.74^{\prime \prime} \mathrm{W}$ \\
\hline 16WP Tizguidelt & $31^{\circ} 57^{\prime} 31.85^{\prime \prime} \mathrm{N} ; 4^{\circ} 27^{\prime} 43.74^{\prime \prime} \mathrm{W}$ \\
\hline 17WP Taghzoute & $31^{\circ} 57^{\prime} 17.99^{\prime \prime} \mathrm{N} ; 4^{\circ} 27^{\prime} 10.20^{\prime \prime} \mathrm{W}$ \\
\hline 18WP Lagssira L'Akedim & $31^{\circ} 57^{\prime} 11.41^{\prime \prime} \mathrm{N} ; 4^{\circ} 27^{\prime} 08.94^{\prime \prime} \mathrm{W}$ \\
\hline 19WP Azemmour L'Akedim & $31^{\circ} 56^{\prime} 51.63^{\prime \prime} \mathrm{N} ; 4^{\circ} 26^{\prime} 47.52^{\prime \prime} \mathrm{W}$ \\
\hline 20EP Tazemmourit & $31^{\circ} 56^{\prime} 45.21^{\prime \prime} \mathrm{N} ; 4^{\circ} 25^{\prime} 59.61^{\prime \prime} \mathrm{W}$ \\
\hline $21 \mathrm{WP}$ Targa & $31^{\circ} 56^{\prime} 19.12^{\prime \prime} \mathrm{N} ; 4^{\circ} 25^{\prime} 52.50^{\prime \prime} \mathrm{W}$ \\
\hline 22EP Oulad el Haj & $31^{\circ} 56^{\prime} 19.12^{\prime \prime} \mathrm{N} ; 4^{\circ} 25^{\prime} 52.50^{\prime \prime} \mathrm{W}$ \\
\hline 23EP Zaouia Moulay Abdellah & $31^{\circ} 55^{\prime} 42.17^{\prime \prime} \mathrm{N} ; 4^{\circ} 23^{\prime} 39.03^{\prime \prime} \mathrm{W}$ \\
\hline 24EP Oulad el Haj L’Akedim & $31^{\circ} 55^{\prime} 33.16^{\prime \prime} \mathrm{N} ; 4^{\circ} 23^{\prime} 42.48^{\prime \prime} \mathrm{W}$ \\
\hline 25EP DD'Akhlani Fokani & $31^{\circ} 55^{\prime} 23.59^{\prime \prime} \mathrm{N} ; 4^{\circ} 24^{\prime} 08.00^{\prime \prime} \mathrm{W}$ \\
\hline 26EP Oulad Bounafi & $31^{\circ} 55^{\prime} 15.13^{\prime \prime} \mathrm{N} ; 4^{\circ} 23^{\prime} 43.76^{\prime \prime} \mathrm{W}$ \\
\hline 27EP DD'Akhla L'Tahtani & $31^{\circ} 55^{\prime} 00.91^{\prime \prime} \mathrm{N} ; 4^{\circ} 23^{\prime} 37.01^{\prime \prime} \mathrm{W}$ \\
\hline 28EP Ait M'Saud & $31^{\circ} 54^{\prime} 56.48^{\prime \prime} \mathrm{N} ; 4^{\circ} 23^{\prime} 27.42^{\prime \prime} \mathrm{W}$ \\
\hline 29EP El Barrani & $31^{\circ} 55^{\prime} 07,87^{\prime \prime} \mathrm{N} ; 4^{\circ} 22^{\prime} 55,82^{\prime \prime} \mathrm{W}$ \\
\hline 30EP Ksiba & $31^{\circ} 55^{\prime} 01,63^{\prime \prime} \mathrm{N} ; 4^{\circ} 22^{\prime} 50,56^{\prime \prime} \mathrm{W}$ \\
\hline 31EP Zaouia Moulay Ben Ali & $31^{\circ} 54^{\prime} 54,58^{\prime \prime} \mathrm{N} ; 4^{\circ} 22^{\prime} 38,70^{\prime \prime} \mathrm{W}$ \\
\hline 32EP Taourirt & $31^{\circ} 54^{\prime} 50,59^{\prime \prime} \mathrm{N} ; 4^{\circ} 22^{\prime} 41,27^{\prime \prime} \mathrm{W}$ \\
\hline 33EP Sidi Bou Abdellah & $31^{\circ} 54^{\prime} 13,15^{\prime \prime} \mathrm{N} ; 4^{\circ} 22^{\prime} 09,86^{\prime \prime} \mathrm{W}$ \\
\hline 34EP Titaf & $31^{\circ} 53^{\prime} 59,79^{\prime \prime} \mathrm{N} ; 4^{\circ} 21^{\prime} 16,99^{\prime \prime} \mathrm{W}$ \\
\hline 35WP Beni M'Hali & $31^{\circ} 53^{\prime} 47,82^{\prime \prime} \mathrm{N} ; 4^{\circ} 22^{\prime} 29,08^{\prime \prime} \mathrm{W}$ \\
\hline 36EP Sin designación 1 & $31^{\circ} 54^{\prime} 50,59^{\prime \prime} \mathrm{N} ; 4^{\circ} 22^{\prime} 41,27^{\prime \prime} \mathrm{W}$ \\
\hline 37EP Tazrout Beni Fousse & $31^{\circ} 53^{\prime} 47,82^{\prime \prime} \mathrm{N} ; 4^{\circ} 22^{\prime} 29,08^{\prime \prime} \mathrm{W}$ \\
\hline 38EP Kasbah Kdima Oulad Mohamed & $31^{\circ} 53^{\prime} 36,58^{\prime \prime} \mathrm{N} ; 4^{\circ} 20^{\prime} 34,72^{\prime \prime} \mathrm{W}$ \\
\hline 39 WP Asrir & $31^{\circ} 53^{\prime} 27,68^{\prime \prime} \mathrm{N} ; 4^{\circ} 22^{\prime} 20,14^{\prime \prime} \mathrm{W}$ \\
\hline 40EP Oulad Mohamed (norte) & $31^{\circ} 53^{\prime} 23,60^{\prime \prime} \mathrm{N} ; 4^{\circ} 20^{\prime} 36,15^{\prime \prime} \mathrm{W}$ \\
\hline 41EP Oulad Mohamed (sur) & $31^{\circ} 53^{\prime} 23,60^{\prime \prime} \mathrm{N} ; 4^{\circ} 20^{\prime} 36,15^{\prime \prime} \mathrm{W}$ \\
\hline 42WP Tissagdelt & $31^{\circ} 53^{\prime} 17,70^{\prime \prime} \mathrm{N} ; 4^{\circ} 21^{\prime} 48,03^{\prime \prime} \mathrm{W}$ \\
\hline 43WP Hdibouz (norte) & $31^{\circ} 52^{\prime} 58,96 " \mathrm{~N} ; 4^{\circ} 21^{\prime} 13,60^{\prime \prime} \mathrm{W}$ \\
\hline 44WP Hdibouz (sur) & $31^{\circ} 52^{\prime} 55,76^{\prime \prime} \mathrm{N} ; 4^{\circ} 21^{\prime} 18,38^{\prime \prime} \mathrm{W}$ \\
\hline 45WP Mediouna Jdid & $31^{\circ} 52^{\prime} 46,50^{\prime \prime} \mathrm{N} ; 4^{\circ} 21^{\prime} 00,81^{\prime \prime} \mathrm{W}$ \\
\hline 46WP Mediouna L'Akedim & $31^{\circ} 52^{\prime} 43,12^{\prime \prime} \mathrm{N} ; 4^{\circ} 20^{\prime} 52,33^{\prime \prime} \mathrm{W}$ \\
\hline 47EP Tazuka & $31^{\circ} 53^{\prime} 01,33^{\prime \prime N} ; 4^{\circ} 20^{\prime} 43,18^{\prime \prime} \mathrm{W}$ \\
\hline 48EP Gaouz & $31^{\circ} 53^{\prime} 01,45^{\prime \prime} \mathrm{N} ; 4^{\circ} 20^{\prime} 07,45^{\prime \prime} \mathrm{W}$ \\
\hline 49EP Guiriourgaz & $31^{\circ} 52^{\prime} 53,66^{\prime \prime} \mathrm{N} ; 4^{\circ} 20^{\prime} 12,62^{\prime \prime} \mathrm{W}$ \\
\hline 50EP Sin designación 2 & $31^{\circ} 52^{\prime} 40,16^{\prime \prime} \mathrm{N} ; 4^{\circ} 20^{\prime} 16,03^{\prime \prime} \mathrm{W}$ \\
\hline 51EP Sin designación 3 & $31^{\circ} 52^{\prime} 36,77^{\prime \prime N} ; 4^{\circ} 20^{\prime} 07,98^{\prime \prime} \mathrm{W}$ \\
\hline 52EP Taznakht L'Akedim & $31^{\circ} 52^{\prime} 22,28^{\prime \prime} \mathrm{N} ; 4^{\circ} 19^{\prime} 20,59^{\prime \prime} \mathrm{W}$ \\
\hline 53WP Meski & $31^{\circ} 51^{\prime} 18,45^{\prime \prime} \mathrm{N} ; 4^{\circ} 17^{\prime} 21,48^{\prime \prime} \mathrm{W}$ \\
\hline
\end{tabular}

Table 3. Ksour of the Mdagra oasis. Source: Gil-Piqueras \& Rodríguez-Navarro.

In this inventory, the ksour have been geographically ordered according to the following coding: the number indicates the order from North to South, with number 1 being the northernmost ksar; with the acronym $\mathrm{E}$ and $\mathrm{W}$, their location has been identified with respect to the river bank, East or West respectively.

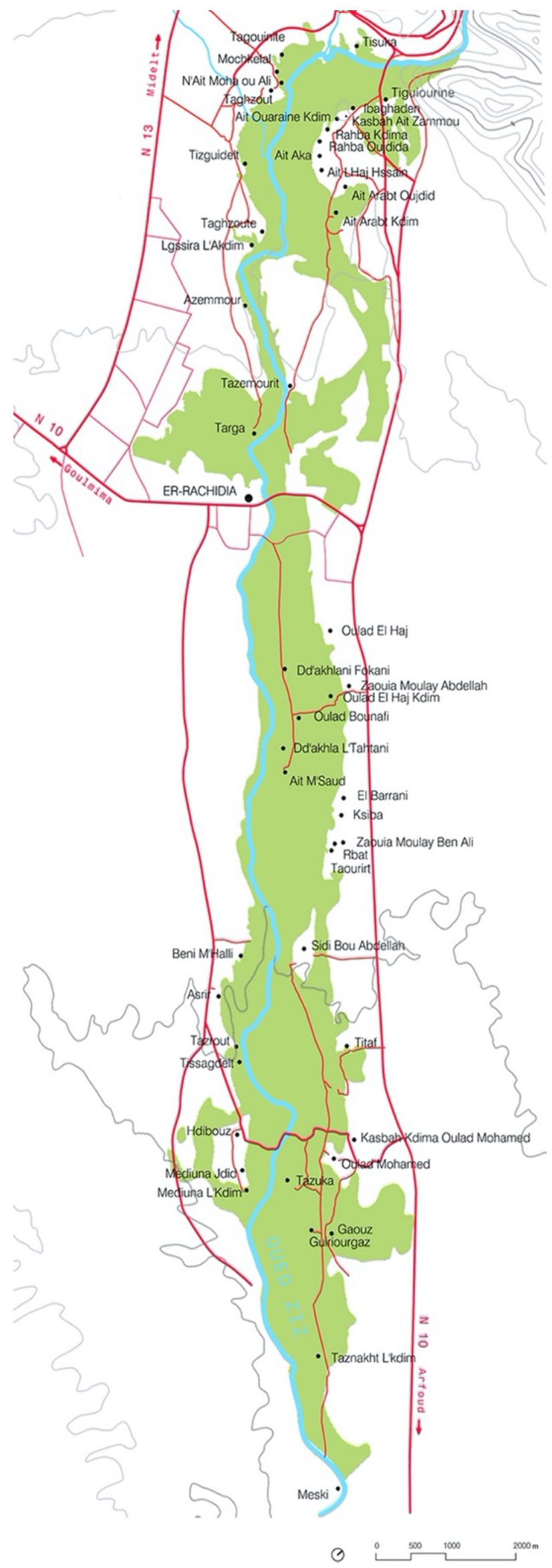

Figure 3. Map of the Madgra oasis with the location of the ksour. Source: Gil-Piqueras \& Rodríguez-Navarro. 


\section{INVARIANTS ANALYSIS}

The architecture of southern Morocco is clearly conditioned by the surrounding environment, so the first of the invariants to study was that of their settlement in the territory. With respect to the morphological configuration of the ksar, we will approach a bidimensional study: that of its formal exterior appearance and that of its internal organization. Finally, the ksour have been studied in relation to the area they occupy.

\subsection{Territorial settlement}

The Er-Rachidia province is characterized by being a pre-desert area in which the scarce arable land is located only along the Ziz river basin, constituting a clearly contrasted boundary with the large plain of barren and dry soil that surrounds it. This fertile land, so necessary for life supporting, has been expanded thanks to the construction of ditches or khetaras that carry water from one area to another, occupying the largest possible area of arable land. Thus, the water supply is organized by building a large network of ditches providing the fields and the $k s o u r$, sometimes getting to distribute the water within the settlement or approximating it to one of its walls. This general network of irrigating ditches is in constant transformation, adapting to agricultural needs and to those of the population itself.

In most of the cases studied in the Mdagra oasis, the ksour are located on the border between the plain and the fertile land, taking special care not to occupy the latter, so they are placed on the plain side. Their situation on it, generally elevated with respect to the cultivable area, also provides them with greater visual control of the territory, increasing the defence capacity of the ksar; although this factor is not decisive, and always prioritizing the proximity to the arable area. Thus, in case of attack by other tribes, the ksar is more accessible to its inhabitants, generally dedicated to rural works.
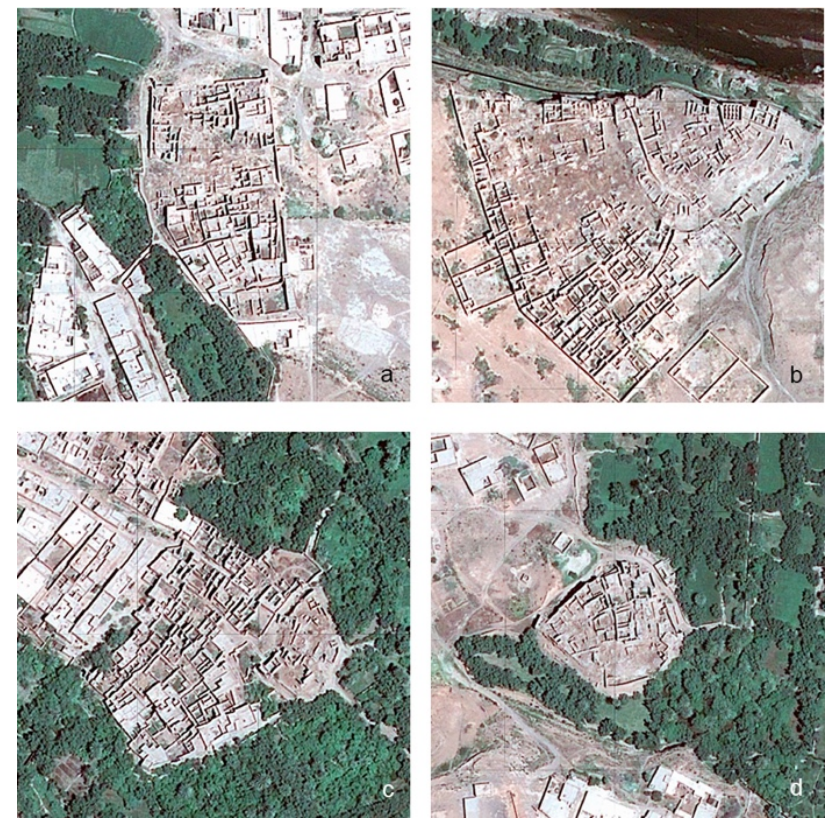

Figure 4. a) Ibaghaden $\operatorname{Ksar}$ (3EP), b) Azemmour L'Akedim Ksar (19WP), c) Tizuka Ksar (1EP), d) Tagounite Ksar (6WP). Source: Google Earth
Regarding the physical boundaries of the ksar, a consequence of human action when constructing a wall, we observed that sometimes it coincides with the geographical limit of the territory, by placing the wall, in its design, at the limit of a natural ground level. This influences the configuration of the floorplan, which seeks to adapt to the territory giving rise in some cases to organic floorplan ksour, far from following a regular geometrical pattern (Figures $4 \mathrm{c}$ and $4 \mathrm{~d}$ ), or to curved alignments in the more regular ksour (Figures $4 \mathrm{a}$ and $4 \mathrm{~b}$ ).

At the level of the ensemble, we see that the disposition of some with respect to others is totally random, concentrating in some places and being dispersed in others, not attending, in principle, to any globally planned defence network.

\subsection{External morphology of the ksar}

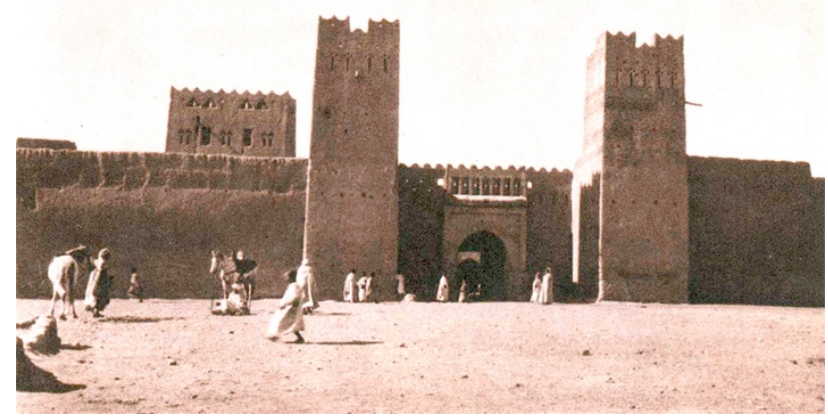

Figure 5. Entrance to the Sidi Bou Abdellah Ksar (33EP). Source: Terrase, 1938.

Morphologically, the Mdagra ksour follow a clear scheme of a defensive structure: they are delimited by a wall equipped with high towers, and in most cases, it is accessed through a single entrance protected by two towers and/or by a double door.

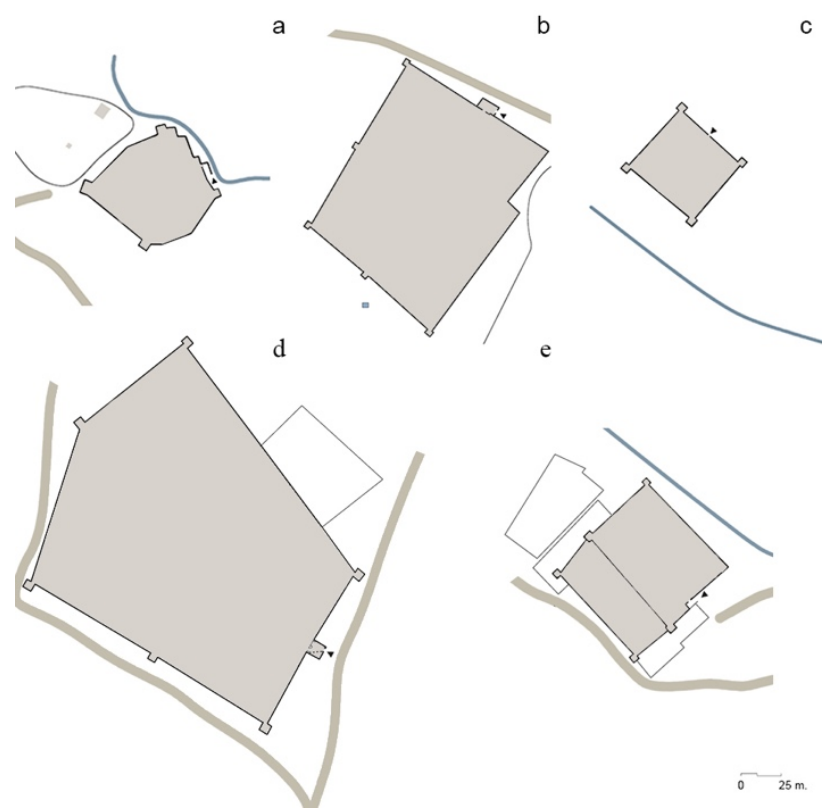

Figure 6. Schematic examples of floorplan boundaries: (a) Tagouinte Ksar (6WP) of organic plan, (b) Hdibouz Ksar (south) (44WP), (c) Ait Akka Ksar (12EP), (d) Titaf Ksar (34EP) and (e) Mouchkelal Ksar (7WP) both fitted to a simple geometrical plan. Source: Gil-Piqueras \& Rodríguez-Navarro. 
After analyzing the floorplans of the ksour of our research, we observed that they follow two clearly differentiated models (Figure 6): while some maintain regular identifiable patterns with simple geometrical shapes, whether square, rectangular or pentagonal, as is the case of the Titaf Ksar, of pentagonal plan; others are very far from all regularity, being their floorplan comparable to organic irregular shapes.

In the case of the former, although they usually present themselves in a pure way facilitating their identification, they sometimes combine and intertwine, making it difficult to distinguish their original shape. This fact can be clearly observed in the case of the ksour that underwent expansion, as is the case of the Beni M'Hali Ksar (Figure 7), in which from a first core of geometrical plan, appreciably square, it can be observed how a new enclosure has been attached to the rear side, which has been given continuity through an opening connecting the two enclosures, expanding the original surface without prejudice to its settler's safety. In the organic plan ksour it is more difficult to identify these extensions, unless they alter their morphology as in the case of the Azemour L'Akedim Ksar (Figure 4b), whose oldest part follows an organic structure, while its extension retains a clearly formal and orderly appearance.

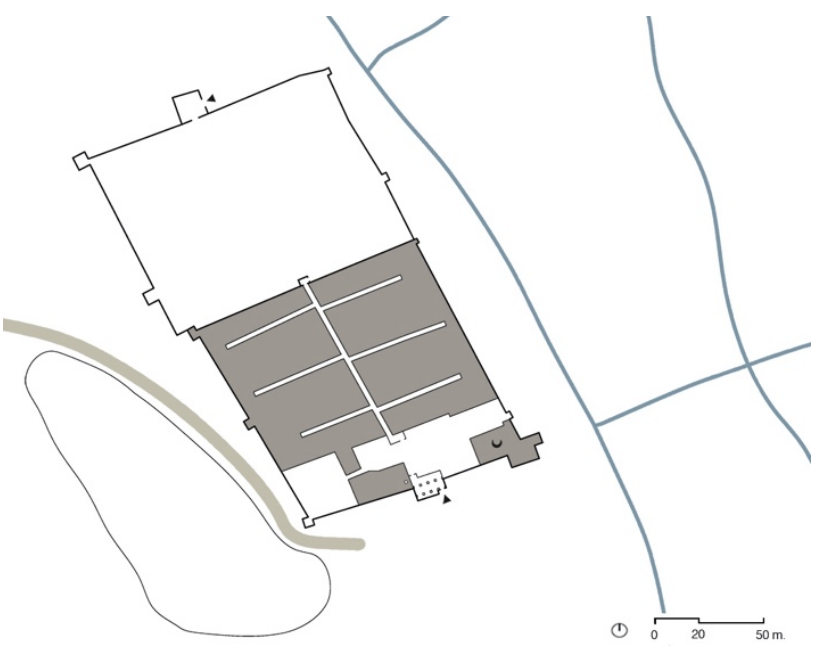

Figure 7. Example of planned expansion in the Beni M'Hali Ksar (35WP). As we have verified at the site, this extension did not consolidate, even lacking the main streets' layout.

Source: Gil-Piqueras \& Rodríguez-Navarro.

On other occasions, this urban planning also attends to the social distribution within the ksar. This is the case of the Targa Ksar (Figure 8), whose concentric layout allows distinguishing different social strata, concentrating in its inner sector the ethnic groups of greater power, and leaving in the outer sector the population dedicated to farmland and to community services.

Even so, if we focus on the external morphology of the ksar, we can state that in general, in the Mdagra oasis, there is a clear distinction between the two types of ksar: the one that maintains an organic plan and the one fitting a geometrical plan. If we analyze the relationship between their settlement in the territory and their morphology, we see that, regardless of their shape, both models are located interchangeably on flat terrains, although it is true that on promontories, we only find organic plan ksour.

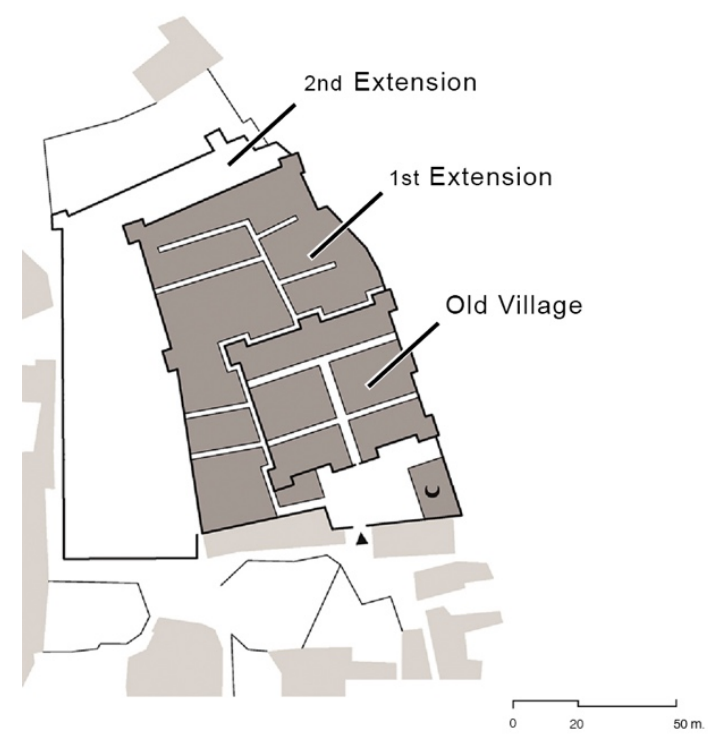

Figure 8. Different walled enclosures, as a result of the expansion of the Targa Ksar (21WP). Source: Gil-Piqueras \& Rodríguez-Navarro.

\subsection{Urban planning}

At an urban level, the ksour analyzed are organized around a plot formed by an orderly arrangement of streets. In large area ksour, the entrance gives access to a large square from which this urban plot emerges. In the smaller ksour, the entrance gives direct passage to a street from which other narrower ones derive. The streets are usually mostly covered, as a result of the expansion of housing above the urban space. Only the intersections between streets remain open to the outside, acting at the same time as light wells and ventilation openings necessary for indoor air renewal. By doing so, the climatic conditions of the ksar are improved, protecting its inhabitants from extreme heat and sandstorms. The soil is kept without paving.

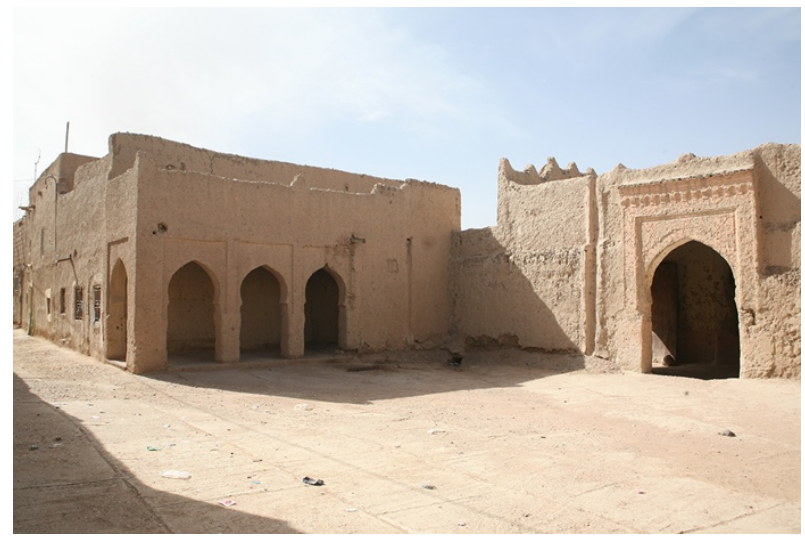

Figure 9. Square located in the access to the interior of the Oulad el Haj Ksar (22EP), in which the facilities for community use are located. Source: Gil-Piqueras \& Rodríguez-Navarro.

Throughout our investigation we have been documenting the width of the streets-which ranges between $1.20 \mathrm{~m}$. and 5.00 m.-; their formal disposition within the ksar; the facilities and services they housed; and their orientation. Based on these parameters we have classified the streets into two types: main and secondary. 


\section{Main street:}

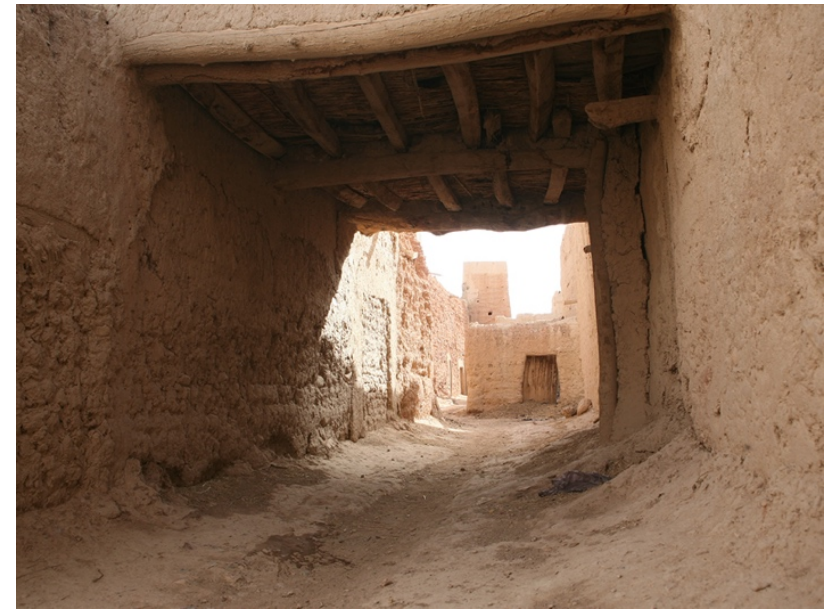

Figure 10. Main street of Rabha Jdid Ksar (11EP). Source: GilPiqueras \& Rodríguez-Navarro.

It arises directly from the main entrance - in general there is only one- extending to the final limit of the ksar or to the point of entry to a new space. The main street is wider than the rest and the facilities for collective use-mosque, madrassa, fonducwhen existent, are located in it, so they can be considered as an urban space for public use. Its disposition within the ksar varies according to cases. In the ksour arranged following a geometrical plan, we find main streets running centered on the ksar, shifted to the side, or according to a branching route from the entrance itself that runs in several directions. This is the case of the Sidi Bou Abdellah Ksar, of a regular geometrical plan, in which we see how three main streets arise from the square following the direction of three different orthogonal axes to lead us to the residential area, to the ksar's community services area, such as the oil mill, the barn and stables, and to the zone where the main residences of the ksar are located, reflecting a great spatial organization.

In the case of the organic structured ksour, the main street is usually centered or following a branched route from the entrance, which is organized in two directions.

If we analyze its orientation, we see that the main street does not follow a specific geographical layout, as some authors have asserted; instead, it depends on the location of the entrance, which is normally situated facing the fertile area. From this street, different types of urban patterns are generated, which mostly follow a regular plot organized from more or less orthogonal axes.

\section{$\underline{\text { Secondary streets: }}$}

They arise perpendicular to the main street, giving way to the most private area of the ksar. In them we find the access doors to the private houses, arranged so they don't face each other with the purpose of preserving the families' intimacy (Youssef Hoteit, 1993).

Depending on the location of the main street, whether centered or shifted to one side, the secondary streets follow two common patterns: either they extend along a continuous axis at both sides of the main street, or they run only on one of its sides. In the case of streets at both sides, we have observed that occasionally their axes do not follow a continuous alignment; instead, from the main street their axis is shifted in parallel, so they do not follow a linear continuity, guaranteeing the intimacy of this urban space and avoiding at the same time the wind is channeled. In the case of organic plan ksour, secondary streets often follow the same patterns.

Within secondary streets we find specific cases of streets fulfilling very specific functions. That is the case of streets for private use, and those aligned to the perimeter of the wall.

Private use streets indicate an exclusive social character within the ksar. Their use establishes a social division between its inhabitants and those of the rest of the ksar. The streets of private use emerge from the main entrance, independently of the rest, and they usually house the family with the highest social position within the ksar. On the contrary, in the case of privately used streets arising from secondary streets, an ethnic difference is usually made, housing either a minority tribe within the $k s a r$, or a population of Jewish origin. These streets are usually separated from the rest of the urban fabric by a gate.

Regarding the streets attached to the intrados of the wall, we have only found them in some large ksour such as the Sidi Bou Abdellah Ksar. Among their functions, one of them is giving access to the wall's parapet walk and to the defensive towers, in most of the ksour accessible from the houses semi-detached to the wall.
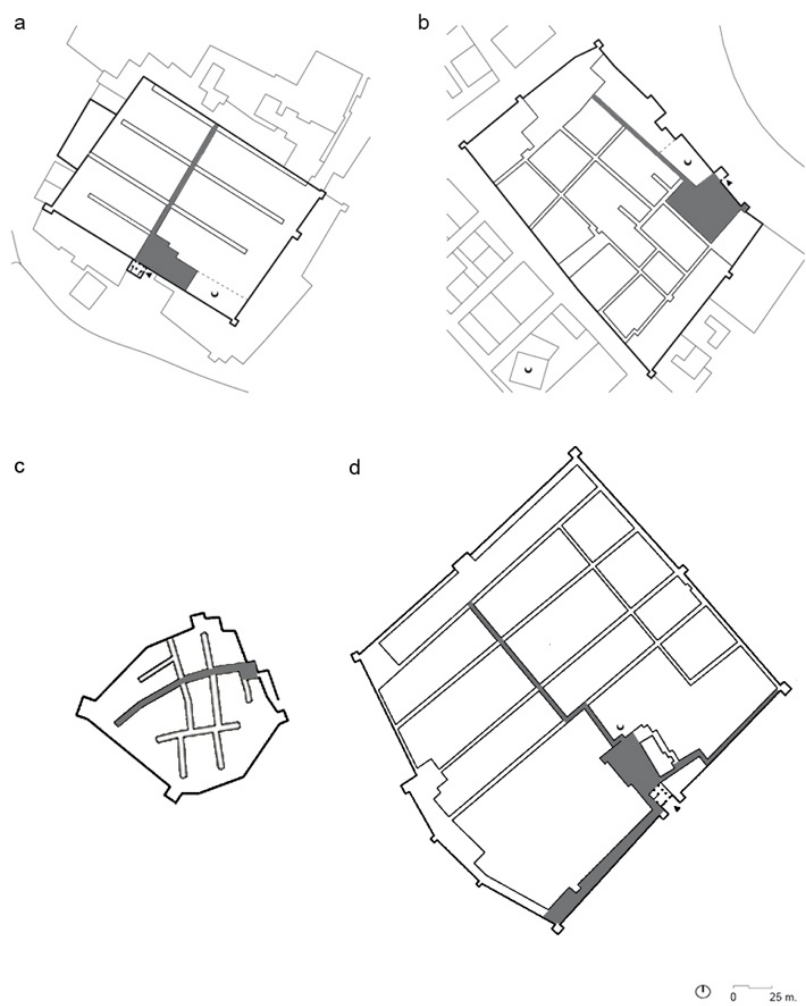

Figure 11. a) Inner urban distribution of the Oulad el Haj Ksar (22EP) with the main street arranged in the center of the ksar,

b) urban plot of the Asrir Ksar (39WP) with the main street placed on one side of the ksar, c) Distribution of the Tagounite Ksar (6WP) of organic plan with central main street; d) Sidi

Bou Abdellah Ksar (33EP), an example of one main street branching into three secondary streets.

Source: Gil-Piqueras \& Rodríguez-Navarro. 


\subsection{Surface of the $k s a r$}

The dimensions of the Mdagra ksour are quite disparate, highlighting among them the Sidi Bou Abdellah Ksar with more than $45,000 \mathrm{~m} 2$ of walled surface. This $k s a r$ was already known in the $16^{\text {th }}$ century for being an outstanding caravan city along the trade route (Meunié, 1982).

Regardless of the total surface of the ksour, we observed how in all of them the area destined for urban space is very small, ranging between $9 \%$ and $15 \%$ of the total area.

\section{RESULTS AND CONCLUSIONS}

We started from the conviction that the approach to the study of the pre-Saharan valleys' ksour must be made from the knowledge of the culture itself. It is the only way to understand their very nature, so characteristic of these valleys, and so difficult to find in other regions, even within Morocco itself.

The research developed in this oasis stems from more than 10 years of study and knowledge of the culture and architecture of the region. From the analysis carried out, we can determine that, morphologically, the Mdagra ksar follows a clear scheme of a defensive structure, defined by the wall, the towers and a double door entrance which is protected. From it, the main street arises, often preceded by a large square.

Based on the ksar morphology, we can see that in the Mdagra oasis there are two clearly differentiated models: one of a regular plan based on simple geometrical shapes, in which the urban plot follows up to three different types of schemes, depending on the layout of its main street; and a second one of totally irregular plan that follows an organic morphology, and whose inner plot is usually developed from a main street that follows a centered layout or branched layout in two directions.

After analyzing its implementation, we observe that only those with an organic plan are normally located on small hills or over elevations, adapting the shape of their plan to the shape of the territory, while those with a geometrical plan are located in flat places or with a slight slope.

\section{URBAN CLASSIFICATION}

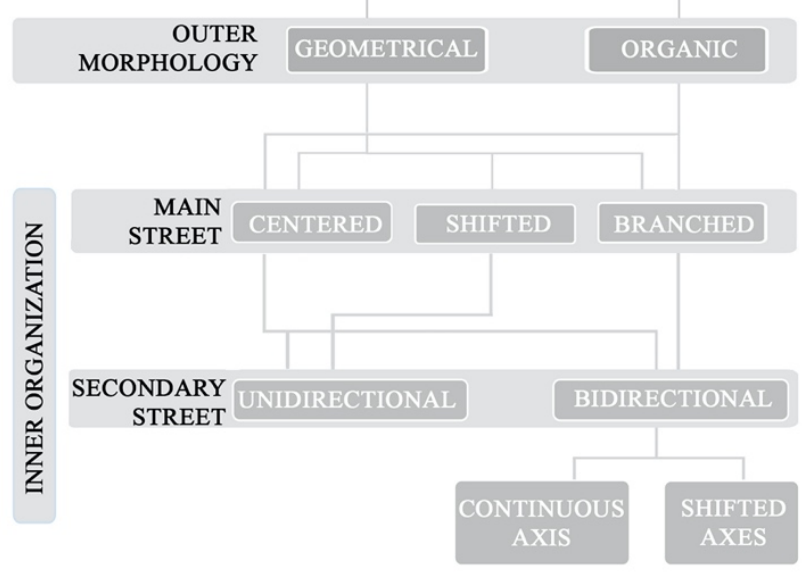

Figure 12. Scheme with the urban classification of the Mdagra oasis ksour. Source: Gil-Piqueras \& Rodríguez-Navarro.
The study of all these determinants leads us to think about the existence of an urban plan from the very origin of the ksar.

Today the lifestyle in the pre-Saharan valleys has changed, the population seeks to live independently, there is no need to inhabit enclosed and fortified spaces to defend against the attacks of neighbouring tribes. A better quality of life, understood as the implementation of western models and more durable materials, is sought. Only some ksour keep part of their population and it is generally those that have been rehabilitated at the government's initiative; this is the case of the Targa Ksar or the Oulad el Haj Ksar, although most have been abandoned.
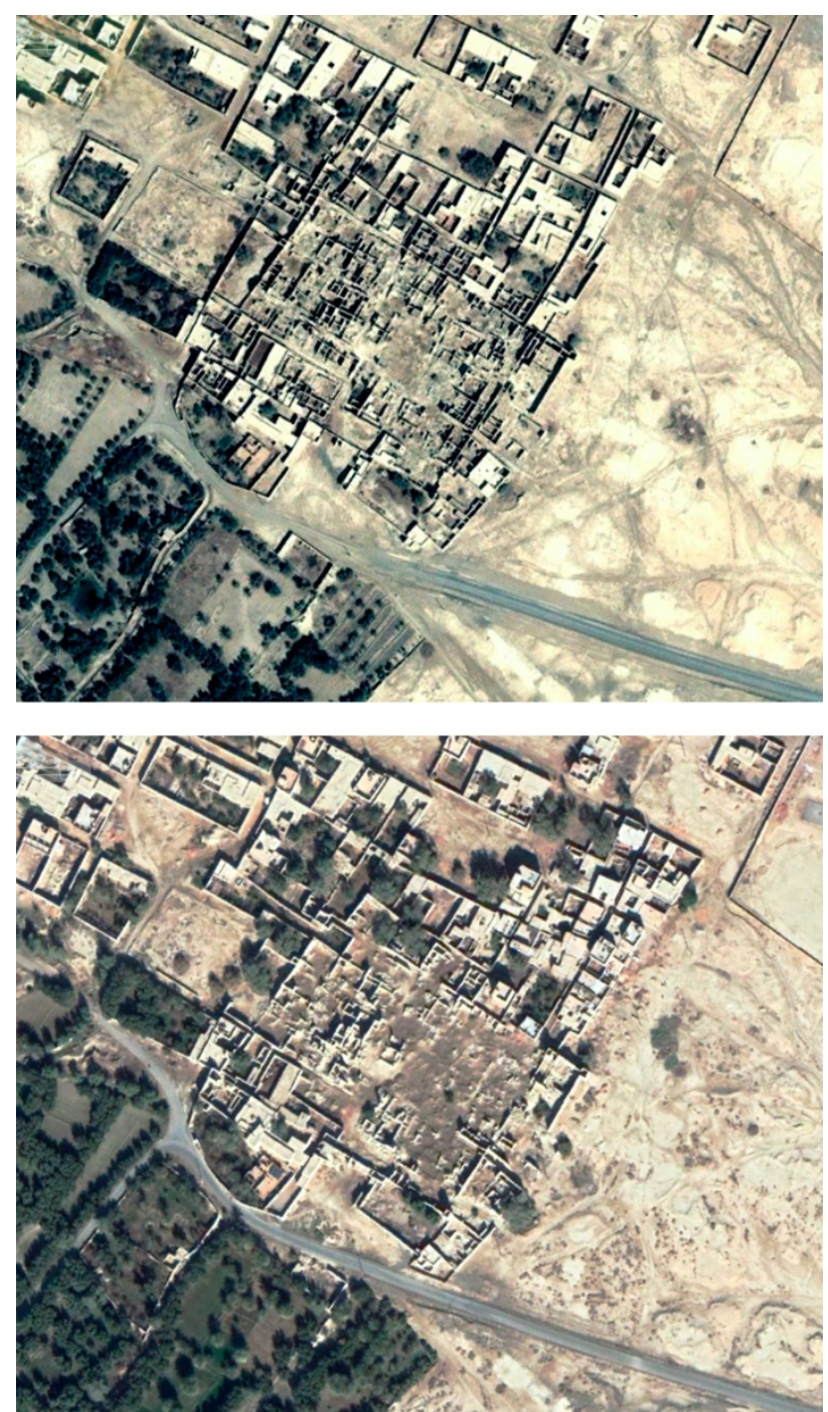

Figure 13. Images showing the deterioration experimented by the Kdima Oulad Mohamed Ksar (40EP) from 2003 to 2019, date on which many of its structures have disappeared. Orthoimage taken in 2003 (above) and orthoimage taken in 2019 (below). Source: Google Earth.

This abandonment leads, in a type of architecture with a great need for maintenance, to a progressive deterioration that finally brings the ksar to a state of ruin and its subsequent disappearance. This is how throughout the different expeditions carried out to the area in recent years, we have been able to verify an acceleration in the process of ruin of these ksour. From the abandonment, a succession of stages takes places as a chain of events ending with the total disappearance of the ksar, which will 
be converted back, as we have already observed in some cases, in what it was initially: a mound of soil. Hence, the importance of their documentation.

\section{REFERENCES}

Carte du Maroc, 1:50.000, Hoja $\mathrm{n}^{\circ} \mathrm{NH}-30-\mathrm{XX}-4 \mathrm{c}$, Ar Rachidia, Dirección para la Conservación forestal y de trabajos topográficos, Ministerio de Agricultura y reforma agraria, Reino de Marruecos, Division de la Cartographie, Rabat, 1985 y 1991.

Chueca Goitia, F., 1982. "El urbanismo islámico", Vivienda y Urbanismo en España. Banco Hipotecario de España, Barcelona, 1982.

Foucauld, Ch., 1888. Reconnaissance au Maroc 1883-84. $1^{\text {a }}$ Ed., Challamel, Paris.

Gil Piqueras, T., Rodríguez-Navarro, P., 2013., "Habitat e territorio nel Alto Atlas Orientale del Marocco". Città e Territorio. Conoscenza, tutela e valorizzazione dei paesaggi culturali. Ed. Debatte, Livorno, pp. 220- 225.

Jacques-Meuniè, D., 1982. Le Maroc saharien des origines au XVIe siècle. Librairie Klincksieck, Paris. p. 128.

Laoust, E., 1934. "L'habitation chez les tranhumants du Maroc central. L'igerm". Hespéris Tamuda. Tomo XVIII, Larose, Paris, p. $159-161$.

Marcais, G., 1970. "L'Urbanisme musulman". Cinquieme congres de la federation des societés savantes de l'Afrique du Nord. Argelia, pp. 13-34.

Marcais, G., 1945. "La concepcion des villes dans l'Islam". Revue d'Alger. Vol II, pp. 517-533.

Marcais, W., 1928. "L' Islamisme et la vie urbaine". Comptes rendues des seances de l'Academie des inscriptions et BellesLettres. pp. 86-100.

Nakhli Mtiri, A., 2006. "La ciudad islámica: sus referencias culturales". La inmigracion y la interculturalidad. Biblioteca Regional de Madrid, http://eprints.ucm.es/20236/.

Navarro Palazón, J., Jiménez Castillo, P., 2007. "Algunas reflexiones sobre el urbanismo islámico”. Antigrama, $\mathrm{n}^{\mathrm{0}} 22$. Dpto. Historia del Arte de la Universidad de Zaragoza, pp. 269292.

Nijst, A.L.M.T. et ali, 1973. Living on the edge of the Sahara. A study of traditional forms of habitation and types of settlement in Morocco. Government Publishing Office, Le Hague.

Rodríguez-Navarro, P., Gil Piqueras, M. T., 2012. "Integrated Methodology for Urban Survey and Representation of the Morocco's High Atlas". In $18^{\text {th }}$ International Conference on Virtual Systems and Multimedia (VSMM 2012), IEEE, Milán.

Sadki, A. "Urbanisme et dègradation de l'habitat traditionnel des oasis du sud-est Marocain: l'exemple del ksour u Tafilalt (Province d'Errachidia)". Magazine d'Architecture en ligne. http://www.archimag. com/eassi_18.php.
Terrase, H., 1938. Kasbas berbères de l'Atlas et des oasis. Editions des Horizons de France. Paris, p. 160.

Verdugo, C., 1982. L'Amenagement de la vallee du Ziz, Maroc, Tesis Doctoral, Ecole Nationale d'Architecture, Université de Paris, vol I, Inédito.

Youssef Hoteit, A., 1993. "Cultura, espacio y organización urbana en la ciudad Islámica". Cuadernos de investigación Urbanística, $\mathrm{n}^{\mathrm{o}} 5.2^{\mathrm{a}}$ edición, Instituto Juan de Herrera, Madrid, p. 21-31. 